\begin{tabular}{ll}
\hline Journal of National Institute of Neurosciences Bangladesh, & ISSN (Online) $2518-6612$ \\
January 2019, Vol. 5, No. 1, pp. 69-71 & ISSN (Print) $2410-8030$ \\
\hline
\end{tabular}

\title{
Rate of Distribution of Breast Lump in Different Quadrants with Their Cytological Findings in Both Sex
}

\author{
Nazmun Nahar ${ }^{1}$, Mohammed Iqbal'², Kazi Md. Shahidur Rahman³, , Nazim Uddin Md. Arif , \\ MD Mizanur Rahman ${ }^{5}$, Towhida Naheen ${ }^{6}$, Mohammed Safiul Alam7, Soma Das ${ }^{8}$ \\ ${ }^{1}$ Associate Professor \& Head, Department of Pathology, Medical College for Women \& Hospital, Dhaka, Bangladesh; ${ }^{2}$ Associate \\ Professor, Department of Anatomy, Monno Medical College, Manikganj, Bangladesh; ${ }^{3}$ Assistant Professor, Department of \\ Pathology, Monno Medical College, Manikgonj, Bangladesh; ${ }^{4}$ Assistant Professor, Department of Urology, Uttara Adhunik \\ Medical College, Dhaka, Bangladesh; ${ }^{5}$ Associate Professor, Department of Urology, Cox's Bazar Medical College, Cox's \\ Bazar, Bangladesh; ${ }^{6}$ Associate Professor, Department of Anatomy, University of Science \& Technology Chittagong \\ (USTC), Chittagong, Bangladesh; ${ }^{7}$ Junior Consultant (Cardiology), Upazila Health Complex, Anowara, Chittagong, \\ Bangladesh; ${ }^{8}$ Assistant Professor, Department of Biochemistry, Southern Medical College, Chittagong, Bangladesh
}

[Received: 12 October 2018; Accepted: 2 November 2018; Published: 1 January 2019]

\begin{abstract}
Background: The breast lump is a localized swelling, protuberance, bulge, or bump in the breast that feels different from the breast tissue around it or the breast tissue in the same area of the other breast. Objective: The purpose of the present study was to find out the frequency of breast lump in different quadrants and their cytological findings. Methodology: The present study was carried out at the Department of Pathology, Chittagong Medical College, Bangladesh one-year period from May 2005 to June 2006. This study was cross sectional which included 110 cases of breast lump. The patients with breast lump were received from indoor and outdoor patient Department of Surgery, Chittagong Medical College, Bangladesh. The patient presents with definite palpable lump, irrespective of age and sex were included in this study. Result: This study shows only $1.8 \%$ male were found central quadrant individual breast. In female maximum (46.4\%) were found in upper \& outer quadrant individual breast. Right sided of affected breast in highest percentage of upper \& outer quadrant individual breast $(21.8 \%)$. Also shows left side of affected breast in highest percentage of upper \& outer quadrant individual breast (24.5\%). It was observed that maximum (34.5\%) upper \& outer quadrant individual breast was seen in benign lesion and $(3.6 \%)$ were suspicious. But maximum (12.7\%) were show multiple in malignant lesion. Conclusion: In conclusion highest frequency of patients are reported in upper outer quadrant breast lump followed by multiple, central, lower \& inner and lower \& outer. It also observed that the upper outer quadrant is the most commonly affected quadrant in benign and multiple quadrant the malignant breast neoplasms. [Journal of National Institute of Neurosciences Bangladesh, 2019;5(1): 69-71]
\end{abstract}

Keywords: Breast Lump; Quadrants of breast; Cytological Findings

Correspondence: Dr. Nazmun Nahar, Associate Professor \& Head, Department of Pathology, Medical College for Women \& Hospital. Uttara. Dhaka, Bangladesh; Cell no.: +8801914140697; Email: iqbal085nahar082@gmail.com

Conflict of interest: There is no conflict of interest relevant to this paper to disclose.

Funding agency: This research project was not funded by any group or any institution.

Contribution to authors: Nahar N, Iqbal M, Rahman KMS, Alam MS have contributed from the protocol preparation, data collection up to report writing. Manuscript writing was performed by Rahaman MM, Naheen T, Das S, Arif NUM. Statistical analysis was performed by Nahar N, Iqbal M. Iqbal M has involved in supervision of the research work and revision of manuscript. How to cite this article: Nahar N, Iqbal M, Rahman KMS, Alam MS, Rahaman MM, Naheen T, Das S, Arif NUM. Rate of Distribution of Breast Lump in Different Quadrants with Their Cytological Findings in Both Sex. J Natl Inst Neurosci Bangladesh, 2019;5(1): 69-71

Copyright: (O2019. Nahar et al. Published by Journal of National Institute of Neurosciences Bangladesh. This article is published under the Creative Commons CC BY-NC License (https://creativecommons.org/licenses/by-nc/4.0/). This license permits use, distribution and reproduction in any medium, provided the original work is properly cited, and is not used for commercial purposes.

\section{Introduction}

Breast lump is the most common reason for presenting to surgery departments. Most of these patients, however, are in a state of heightened anxiety until they have undergone specialist assessment, the necessary investigations and eventual reassurance. The majority of patients referred to a surgery department is said to have benign disease $\mathrm{e}^{1-3}$. Fibroadenoma is the most common of the benign breast diseases ${ }^{4-7}$.

Many studies have shown that the upper outer quadrant of the breast is the most frequent site for occurrence of breast cancer ${ }^{8-9}$. The upper outer quadrant had the highest breast area and the highest dense area, with a $20 \%$ density. The lower outer quadrant had the majority of 
cancer $(60.9 \%)$, followed by the lower inner quadrant (18.2\%), the upper inner quadrant (14.5\%), and the lower outer quadrant (6.4\%). An adequate explanation for this asymmetric occurrence of breast cancer within the breast has never been established. Since density is a risk factor, it would be very interesting to investigate the relationship between quadrant density and the tumor occurring quadrant location ${ }^{10}$. This present study was undertaken to find out the frequency of breast lump in different quadrants and their cytological findings.

\section{Methodology}

This cross-sectional study was carried out at the Department of Pathology at Chittagong Medical College, Chittagong, Bangladesh for one-year period from May 2005 to June 2006. The patients with breast lump were received from indoor and outdoor patient Department of Surgery, Chittagong Medical College, Bangladesh. The patient presented with definite palpable lump, irrespective of age and sex were included in this study. FNA was done in all patients. After collection, the tissue was smeared on glass slide and fixed in $95.0 \%$ alcohol for Papanicolaou's staining. The smear was prepared slowly forward with an "up and down" movement with another slide inclined at an angle of 45 degrees, over the drop. The smeared slides were promptly dipped in $95 \%$ ethyl alcohol for fixation and to prevent drying artifacts. The smear prepared from FNA was stained by pap's stain. All tissues were study cytologically and all data were statistically evaluated in SPSS version 17.

\section{Results}

This study was cross sectional which included 110 cases of breast lump.

Table 1 shows only $1.8 \%$ male were found central quadrant individual breast. In female maximum (46.4\%) were found in upper \& outer quadrant individual breast.

The right side of affected breast has in the highest percentage of upper \& outer quadrant individual breast $(21.8 \%)$ and also showed left side of affected breast in highest percentage of upper \& outer quadrant individual breast (24.5\%) (Table 2).

Table 2: Distribution of Breast Lump According To Location and Side of the Breast $(\mathrm{n}=110)$

\begin{tabular}{lccc}
\hline Quadrant of & \multicolumn{2}{c}{ Side of affected breast } & Total \\
\cline { 2 - 3 } Individual Breast & Right & Left & \\
\hline Upper \& Outer & $24(21.8 \%)$ & $27(24.5 \%)$ & $51(46.4 \%)$ \\
Upper \& Inner & $9(8.2 \%)$ & $5(4.5 \%)$ & $14(12.7 \%)$ \\
Lower \& outer & $1(0.9 \%)$ & $1(0.9 \%)$ & $2(1.8 \%)$ \\
Lower \& Inner & $1(0.9 \%)$ & $3(2.7 \%)$ & $4(3.6 \%)$ \\
Central & $7(6.4 \%)$ & $8(7.3 \%)$ & $15(13.6 \%)$ \\
Multiple & $11(10.0 \%)$ & $13(11.8 \%)$ & $24(21.8 \%)$ \\
Total & $\mathbf{5 3 ( 4 8 . 2 \% )}$ & $\mathbf{5 7 ( 5 1 . 8 \% )}$ & $\mathbf{1 1 0}(\mathbf{1 0 0 . 0 \% )}$ \\
\hline
\end{tabular}

In table 3 it was observed that maximum (34.5\%) upper $\&$ outer quadrant individual breast was seen in benign lesion and $(3.6 \%)$ were suspicious. But maximum $(12.7 \%)$ were show multiple in malignant lesion. Others on depicted in tables.

Table 1: Distribution of Breast Lump in Different Quadrants of Both Sex $(n=110)$

\begin{tabular}{lccccccc}
\hline Sex & & \multicolumn{2}{c}{ Quadrant Individual breast } & \multicolumn{2}{c}{ Total } \\
\cline { 2 - 6 } & Upper \& Outer & Upper \& Inner & Lower \& outer & Lower \& Inner & Central & Multiple & \\
\hline Mole & $0(00)$ & No(\%) & No(\%) & No(\%) & No(\%) & No(\%) & No(\%) \\
Female & $51(46.4 \%)$ & $14(12.7 \%)$ & $2(1.8)$ & $0(00)$ & $2(1.8)$ & $0(00)$ & $2(1.8)$ \\
Total & $\mathbf{5 1}(\mathbf{4 6 . 4 \% )}$ & $\mathbf{1 4}(\mathbf{1 2 . 7} \%)$ & $\mathbf{2}(\mathbf{1 . 8})$ & $\mathbf{4 ( 3 . 6 )}$ & $\mathbf{1 5}(\mathbf{1 3 . 6 )}$ & $\mathbf{2 4}(\mathbf{2 1 . 8})$ & $\mathbf{1 1 0}(\mathbf{1 0 0})$ \\
\hline
\end{tabular}

Table 3: Cytological findings of breast lump found in different quadrants $(n=110)$

\begin{tabular}{|c|c|c|c|c|c|c|}
\hline \multirow{3}{*}{$\begin{array}{l}\text { Quadrant of } \\
\text { Individual } \\
\text { Breast }\end{array}$} & \multicolumn{4}{|c|}{ Cytological findings } & \multirow[t]{2}{*}{ Total } & \multirow[t]{3}{*}{ P value } \\
\hline & Benign & Malignant & Inflammatory & Suspicious & & \\
\hline & No(\%) & No(\%) & No(\%) & No(\%) & No(\%) & \\
\hline Upper \& Outer & $38(34.5)$ & $9(8.2)$ & $0(00)$ & $4(3.6)$ & $51(46.4)$ & \\
\hline Upper \& Inner & $8(7.3)$ & $6(5.5)$ & $0(00)$ & $0(00)$ & $14(12.7)$ & \\
\hline Lower \& outer & $1(0.9)$ & $0(00)$ & $0(00)$ & $1(0.9)$ & $2(1.8)$ & \\
\hline Lower \& Inner & $1(0.9)$ & $3(2.7)$ & $0(00)$ & $0(00)$ & $4(3.6)$ & 0.001 \\
\hline Central & $9(8.2)$ & $4(3.6)$ & $2(1.8)$ & $0(00)$ & $15(13.6)$ & \\
\hline Multiple & $9(8.2)$ & $14(12.7)$ & $1(0.9)$ & $0(00)$ & $24(21.8)$ & \\
\hline Total & $66(60)$ & $36(32.7)$ & $3(2.7)$ & $5(4.5)$ & $110(100)$ & \\
\hline
\end{tabular}




\section{Discussion}

The present study was carried out at the Department of Pathology, Chittagong Medical College, Bangladesh one-year period from May 2005 to June 2006. This study was cross sectional which included 110 cases of breast lump. The patients with breast lump were received from indoor and outdoor patient Department of Surgery, Chittagong Medical College, Bangladesh. In this study shows only $1.8 \%$ male were found central quadrant individual breast. In female maximum $(46.4 \%)$ were found in upper \& outer quadrant individual breast. These findings consistent with others studies ${ }^{4,6,7}$.

In the present study, both sides (right and left) were almost equally involved by the different types of cytological lesions. This is in contrast with the findings of Meena et $\mathrm{al}^{11}$, Reddy and Reddy ${ }^{12}$ and Clegg-Lamptey and Hodasi ${ }^{13}$ in which the left side was slightly more common.

Upper and outer quadrant was the most commonly involved quadrant $(46.4 \%)$ in the present study. This is in agreement with the findings of other studies like Zuk et $\mathrm{a}^{14}(42.20 \%)$, Reddy and Reddy ${ }^{15}(54.20 \%)$, Meena et $\mathrm{al}^{11}(54 \%)$ and Clegg-Lamptey and Hodasi ${ }^{13}$ $(42.40 \%)$. The exact cause of this finding is not known. In the present study, more benign cases and less malignant were found histologically than studies by Mohammed et a ${ }^{15}$, Kim et all6 and Choi et a ${ }^{17}$ This higher number of benign and lower number of malignant cases in other studies may be due to good follow up or more awareness amongst the patients.

It was observed that maximum (34.5\%) upper \& outer quadrant individual breast was seen in benign lesion and $(3.6 \%)$ were suspicious. However, maximum $(12.7 \%)$ were show multiple in malignant lesion. This is in agreement with the findings of other studies ${ }^{5,11,13}$.

\section{Conclusion}

This study shows highest of frequency of patients were upper outer quadrant then multiple, central, lower \& inner and lower \& outer. It also observed that the upper outer quadrant was the most commonly affected quadrant in benign and multiple quadrant the malignant breast neoplasms. Further investigation using exactly the same quadrant division method is needed to explore the direct association of quadrant breast cytology with cancer occurrence risk.

\section{References}

1. Osime OC Ohanaka EC Analysis of five-year breast biopsies carried out in the University of Benin Teaching Hospital Benin City. Niger Postgrad Med J. 2008 ;15(3):160-163.

2. Ohene-Yeboah MO. An audit of excised breast lumps in Ghanaian women. West Afr J Med. 2005;24(3):252-255.

3. Clegg-Lamptey JN, Aduful HK, Yarney J, Adu- Aryee NA, Vanderpuye V, Kyereh M, et al. Profile of breast disease at a self-referral clinic in Ghana.NepalMedColl J. 2004;6(2):129-132.

4. Oluwole SF, Freeman HP. Analysis of benign breast lesions in blacks. Am J Surg. 1979;137(6):786-789.

5. Sönmez K, Türkyilmaz Z, Karabulut R, Demiroðullari B, Ozen IO, Moralioðlu S, Surgical breast lesions in adolescent patients and a review of the literature. Acta Chir Belg. 2006 JulAug;106(4):400-404.

6. Adeniji KA, Adelusola KA, Odesanmi WO. Benign disease of the breast in Ile-Ife: a 10-year experience and literature review. Cent Afr J Med. 1997;43(5):140-143.

7. Ihekwaba FN. Benign breast disease in Nigerian women: a study of 657 patients. J R Coll Surg Edinb. 1994;39(5):280-283.

8. Lee AH. Why is carcinoma of the breast more frequent in the upper outer quadrant? A case series based on needle core biopsy diagnoses. Breast. 2005;14(2):151-152.

9. Darbre PD. Recorded quadrant incidence of female breast cancer in Great Britain suggests a disproportionate increase in the upper outer quadrant of the breast. Anticancer Res. $2005 ; 25(3 \mathrm{c}): 2543-2550$

10. Chan S, Chen J-H, Li S, et al. Evaluation of the association between quantitative mammographic density and breast cancer occurred in different quadrants. BMC Cancer 2017 17:274.

11. Meena SP, Hemrajani DK, Joshi N. A comparative and evaluative study of cytological and histological grading system profile in malignant neoplasm of breast-An important prognostic factor. Indian J Pathol Microbiol. 2006;49:199-202.

12. Reddy DG, Reddy CRR. Carcinoma of the breast, its incidence and histological variants among South Indians. Indian J Med Sci. $1958 ; 12: 228-34$

13. Clegg-Lamptey J, Hodasi W. A study of breast cancer in Korle $\mathrm{Bu}$ teaching hospital: Assessing the impact of health education. Ghana Med J. 2007;41:72-7.

14. Zuk JA, Maudsley G, Zakhour HD. Rapid reporting on fine needle aspiration of breast lumps in outpatients. J Clin Pathol. 1989;42:906-11

15. Mohammed AZ, Edino ST, Ochicha O, Alhassan SU. Value of fine needle aspiration biopsy in preoperative diagnosis of palpable breast lumps in resource-poor countries: A Nigerian experience. Ann Afr Med. 2005;4:19-22.

16. Kim A, Lee J, Choi JS, Won NH, Koo BH. Fine needle aspiration cytology of the breast. Experience at an outpatient breast clinic. Acta Cytol. 2000;44:361-7.

17. Choi YD, Choi YH, Lee JH, Nam JH, Juhng SW, Choi C. Analysis of fine needle aspiration cytology of the breast: A review of 1,297 cases and correlation with histologic diagnoses. Acta Cytol. 2004;48:801-6. 